\title{
Spectroscopic Studies and DFT Calculations of Cimetidine Complexes with Transition Metal Ions
}

Daniela Olea-Román, ${ }^{\mathrm{a} J u a n}$ Carlos Villeda-García, ${ }^{\mathrm{a}}$ Raúl Colorado-Peralta, ${ }^{\mathrm{a}, \mathrm{d}}$ Alejandro Solano-Peralta, ${ }^{\mathrm{b}}$ Mario Sanchez, ${ }^{\mathrm{c}}$ Irán F. Hernández-Ahuactzi, ${ }^{\mathrm{c}}$ and Silvia Elena Castillo-Blum, ${ }^{\mathrm{a}, *}$

a Departamento de Química Inorgánica, ${ }^{\text {b }}$ Unidad de Servicios y Apoyo a la Investigación, Facultad de Química, Universidad Nacional Autónoma de México, Ciudad Universitaria, C.P. 04510, D.F., México,

c Centro de Investigación en Materiales Avanzados, S.C. Alianza Norte 202, PIIT, Carretera Monterrey-Aeropuerto Km. 10, C.P. 66600, Apodaca N.L., México.

${ }^{d}$ Facultad de Ciencias Químicas, Universidad Veracruzana, Prolongación de Oriente 6, No. 1009, Col. Rafael Alvarado, C.P. 94340, Orizaba, Ver., México.

blum@unam.mx

Received February 27, 2013; Acepted July 19, 2013.

\begin{abstract}
The coordination behavior of the antiulcer drug cimetidine (cime) towards transition metal ions was investigated. The synthesis and characterization of $\left[\mathrm{Cr}(\mathrm{cime})_{2} \mathrm{Cl}_{2}\right] \mathrm{Cl} \cdot 3 \mathrm{H}_{2} \mathrm{O},\left[\mathrm{Co}(\right.$ cime $\left.) \mathrm{Cl}_{2}\right] \cdot 5 \mathrm{H}_{2} \mathrm{O}$, $\left[\mathrm{Co}(\text { cime })_{3} \mathrm{Cl}\right] \mathrm{Cl} \cdot 3 \mathrm{H}_{2} \mathrm{O},\left[\mathrm{Ni}(\right.$ cime $\left.) \mathrm{Cl}_{2}\left(\mathrm{H}_{2} \mathrm{O}\right)_{2}\right] \cdot \mathrm{H}_{2} \mathrm{O},\left[\mathrm{Cu}(\right.$ cime $\left.) \mathrm{Cl}_{2}\right] \cdot 2 \mathrm{H}_{2}$ $\mathrm{O},\left[\mathrm{Cu}(\text { cime })_{2} \mathrm{Cl}\left(\mathrm{H}_{2} \mathrm{O}\right)\right] \mathrm{Cl} \cdot \mathrm{H}_{2} \mathrm{O},\left[\mathrm{Cu}(\text { cime })_{3} \mathrm{Cl}_{2}\right] \cdot 3 \mathrm{H}_{2} \mathrm{O},\left[\mathrm{Cu}_{2}(\mathrm{cime}) \mathrm{Cl}_{4}\right]$, and $\left[\mathrm{Zn}(\mathrm{cime}) \mathrm{Cl}_{2}\right] \cdot 1.5 \mathrm{H}_{2} \mathrm{O}$ are discussed, where cime acts as monodentate (imidazole N3) or bidentate ligand (N3 and S8). IR, UV-vis, EPR and NMR spectroscopies, mass spectrometry $(\mathrm{FAB}+)$, were employed for the characterization. In order to identify the most reactive areas of cimetidine, the electrostatic potential map of the ligand was calculated; also the structures of minimum energy of the coordination compounds were modeled using DFT (B3LYP/def2-TZVP) calculations.

Key words: cimetidine, coordination compounds, spectroscopic characterization, transition metals, DFT calculations, structural analysis.
\end{abstract}

\section{Introduction}

Cimetidine, (scheme 1), 2-cyano-1-methyl-3-(2-[(5-methyl$1 H$-imidazol-4-yl)-methyl-thio]-ethyl)-guanidine, is a potent histamine $\mathrm{H}_{2}$-receptor antagonist, which inhibits excessive acid secretion caused by histamine, and is used for treatment of peptic ulcer [1]. This drug has the ability to chelate metal ions in blood plasma and in different tissues [2], and it had previously been suggested that the main therapeutic action of cimetidine might be mediated by its interactions with essential metal ions [3]. It resulted interesting to find out whether cimetidine could compete for $\mathrm{Cu}^{\mathrm{II}}$ ion against biological ligands such as albumin [1]. Therefore, the coordination chemistry of cimetidine (cime) has been investigated for some time. The X-ray crystal structures of $\left[\mathrm{Cu}(\text { cime })_{2}\right]\left(\mathrm{ClO}_{4}\right)_{2}$, was reported in 1980 [4], later on, the polymeric structure of $\left[\mathrm{Cu}(\mathrm{cime})_{2}\right]\left(\mathrm{NO}_{3}\right)_{2}$ was discussed [5] and that of $\left[\mathrm{Cu}(\text { cime })_{2}\right] \mathrm{SO}_{4} \cdot 9 \mathrm{H}_{2} \mathrm{O}$ was also published [6]. The X-ray diffraction studies of $\left[\mathrm{Cu}(\text { cime })_{2}\right] \mathrm{X}_{2}(\mathrm{X}$ $=\mathrm{ClO}_{4}{ }^{-}, \mathrm{NO}_{3}{ }^{-}, \mathrm{SO}_{4}{ }^{2-}$ ) reveal solid state structures composed of polymeric cationic $\mathrm{Cu}^{\mathrm{II}}$ complexes and anionic groups [46]. The copper ions are six-coordinated, by two imidazole nitrogens and two thioeter sulfur atoms from two different
Resumen. Se investigó la coordinación del antiulcerante cimetidina (cime) frente a iones metálicos de transición. Se discute la síntesis y caracterización de $\left[\mathrm{Cr}(\text { cime })_{2} \mathrm{Cl}_{2}\right] \mathrm{Cl} \cdot 3 \mathrm{H}_{2} \mathrm{O},\left[\mathrm{Co}(\right.$ cime $\left.) \mathrm{Cl}_{2}\right] \cdot 5 \mathrm{H}_{2} \mathrm{O}$, $\left[\mathrm{Co}(\text { cime })_{3} \mathrm{Cl}\right] \mathrm{Cl} \cdot 3 \mathrm{H}_{2} \mathrm{O},\left[\mathrm{Ni}(\right.$ cime $\left.) \mathrm{Cl}_{2}\left(\mathrm{H}_{2} \mathrm{O}\right)_{2}\right] \cdot \mathrm{H}_{2} \mathrm{O},\left[\mathrm{Cu}(\right.$ cime $\left.) \mathrm{Cl}_{2}\right] \cdot 2 \mathrm{H}_{2}$ $\mathrm{O},\left[\mathrm{Cu}(\text { cime })_{2} \mathrm{Cl}\left(\mathrm{H}_{2} \mathrm{O}\right)\right] \mathrm{Cl} \cdot \mathrm{H}_{2} \mathrm{O},\left[\mathrm{Cu}(\text { cime })_{3} \mathrm{Cl}_{2}\right] \cdot 3 \mathrm{H}_{2} \mathrm{O},\left[\mathrm{Cu}_{2}\left(\right.\right.$ cime $\left.\mathrm{Cl}_{4}\right]$, y $\left[\mathrm{Zn}\right.$ (cime) $\left.\mathrm{Cl}_{2}\right] \cdot 1.5 \mathrm{H}_{2} \mathrm{O}$ donde cime actúa como ligante monodentado (N3 del imidazol) o bidentado (N3 y S8). Los compuestos se caracterizaron mediante IR, espectroscopía electrónica de absorción, RPE, $\mathrm{RMN}$, espectrometría de masas $\left(\mathrm{FAB}^{+}\right)$. Con objeto de identificar las áreas más reactivas de la cimetidina, se calculó el potencial electrostático del ligante, así como las estructuras de mínima energía de los compuestos de coordinación, mediante cálculos DFT (B3LYP/def2TZVP).

Palabras clave: cimetidina, compuestos de coordinación, caracterización espectroscópica, metales de transición, cálculos DFT, análisis estructural.

cimetidine molecules; the coordination sphere is completed by two cyano nitrogens from neighbouring molecules. Soto et al [7] and Bianucci [8] synthesised and characterised by IR and UV-vis absorption spectroscopies, coordination compounds of the type $\left[\mathrm{M}(\mathrm{cime})_{2}\right] \mathrm{X}_{2}\left(\mathrm{M}=\mathrm{Co}^{2+}, \mathrm{Ni}^{2+}, \mathrm{X}=\mathrm{NO}_{3}^{-}\right.$, $\mathrm{BF}_{4}^{-}$[7] and $\mathrm{ClO}_{4}^{-}$[8]). Vibrational spectra (IR and Raman) of cimetidine and their complexes $\left[\mathrm{M}(\text { cime })_{2}\right]\left(\mathrm{ClO}_{4}\right)_{2}$, where $\mathrm{M}$ corresponds to $\mathrm{Cu}^{\mathrm{II}}, \mathrm{Cd}^{\mathrm{II}}, \mathrm{Co}^{\mathrm{II}}$ and $\mathrm{Ni}^{\mathrm{II}}$, were obtained and calculated using semiempirical methods: MNDO, AM1 and PM3 [9].

Electrochemical and potentiometric studies of cimetidine $\mathrm{Cu}^{\mathrm{I} / \mathrm{II}}$ complexes were carried out to find out the stability of the complexes in comparison with those formed by other biological ligands; however, no structural discussion is included [1]. In

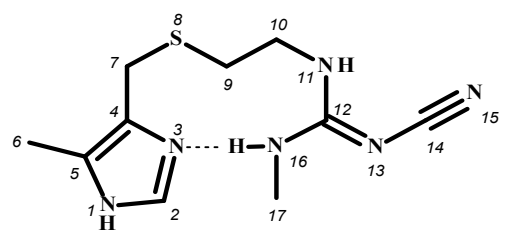

Scheme 1 
that paper it was shown that the stability of the $\mathrm{Cu}^{\mathrm{I}}$-cimetidine complex is enormous therefore it can survive in the presence of biological ligands. Also the chemistry of platinum and palladium with cimetidine has been of interest, a potentiometric and spectroscopic study ( ${ }^{1} \mathrm{H}$ NMR) studies of coordination compounds with $\mathrm{Pd}$ and $\mathrm{Pt}$ is found in the literature $[10,11]$ and later on, the crystal structure of trans-[Pt(cime $\left.)_{2}\right] \mathrm{Cl}_{2} \cdot 12 \mathrm{H}_{2} \mathrm{O}$. To determine the antitumor activity of the drugs, the interaction of the metallic complexes and free cimetidine with DNA was assessed [12].

A solventless synthetic procedure was also employed to obtain $\left[\mathrm{Co}(\mathrm{cime})_{2}\right]\left(\mathrm{SO}_{4}\right)$ and $\left[\mathrm{Ni}(\mathrm{cime})_{2}\right](\mathrm{OAc})_{2}$ where the compounds were characterised by spectroscopic and analytical techniques [13]. There is one report in the literature where the stability constants of the $\mathrm{ML}_{2}$ species $\left(\mathrm{M}=\mathrm{Mn}^{\mathrm{II}}\right.$ and $\left.\mathrm{Ni}^{\mathrm{iI}}\right)$ and $\mathrm{L}=$ cimetidine [2] were determined by a potentiometric method, where the characterisation of the complexes included IR and ${ }^{1} \mathrm{H}$ NMR spectroscopies. Later on, the stability constant of the $\left[\mathrm{Ni}(\mathrm{cime})_{2}\right]^{2+}$ cation in ethanol, at two temperatures, was determined by a spectrophotometric method, showing that a very stable species is formed [14]. The antiulcer activity of a zinc-cimetidine complex in rats has also been studied; however the characterisation of the compound is not discussed [15].

Herein we discuss the synthesis of cimetidine coordination compounds with $\mathrm{Cr}^{\mathrm{III}}, \mathrm{Co}^{\mathrm{II}}, \mathrm{Ni}^{\mathrm{II}}, \mathrm{Cu}^{\mathrm{II}}$ and $\mathrm{Zn}^{\mathrm{II}}$, and were characterized by several spectroscopic techniques (IR, UV-Vis,
${ }^{1} \mathrm{H}$ and ${ }^{13} \mathrm{C}$ NMR, and EPR), so as by mass spectrometry, and elemental analyses. DFT (B3LYP/def2-TZVP) calculations were carried out in order to know the most reactive areas of cimetidine, as well as the structures of minimum energy of the coordination compounds obtained.

\section{Results and Discussion}

There are four known conformation polymorphs of cimetidine: $A, B, C$ and $D$ [16 - 25], that have been characterised by means of IR and ${ }^{13} \mathrm{C}$ NMR spectroscopies [16, 23]. Polymorph $A$ was used in this work, since this is the preferred species used as antiulcer drug [26].

Cimetidine (cime) was reacted with the chlorides of $\mathrm{Cr}^{\mathrm{III}}$, $\mathrm{Co}^{\mathrm{II}}, \mathrm{Ni}^{\mathrm{II}}, \mathrm{Cu}^{\mathrm{II}}$ and $\mathrm{Zn}^{\mathrm{II}}$ in ethanol, using different molar ratios and reaction conditions, depending upon the metal ion. It was observed that cimetidine coordinated either through the imidazolic nitrogen and the thioether sulfur atom, yielding 5-membered rings, or as monodentate using only the imidazolic nitrogen atom, in all cases (see schemes 2 and 3). The coordination compounds obtained in this work are shown in schemes 2 and 3 . A number of different complexes were isolated, since different stoichiometric ratios were employed, all reactions were carried out in ethanol.

Nine coordination compounds (1 - 9) were obtained using chlorides of the first row transition metal ions.

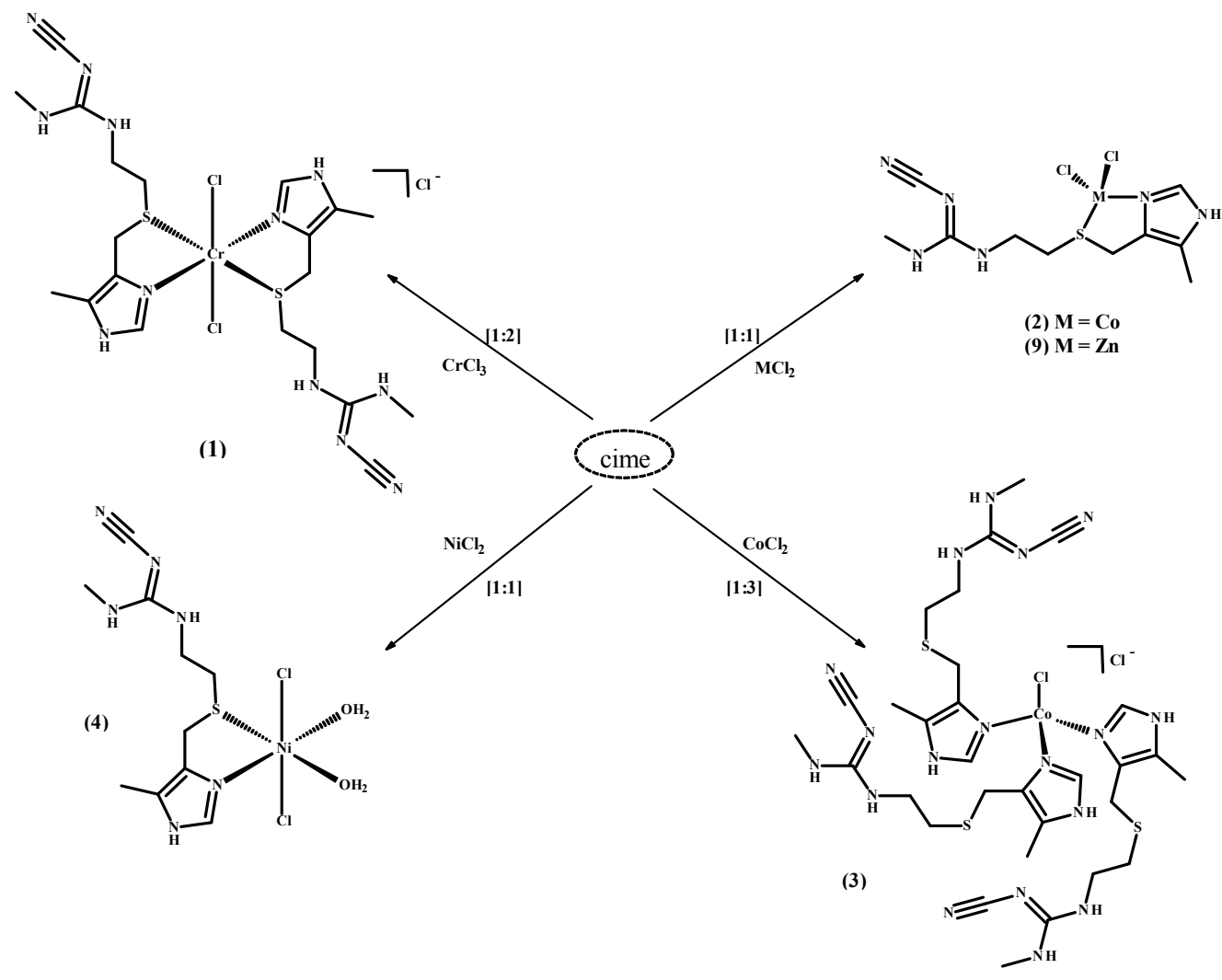

Scheme 2 


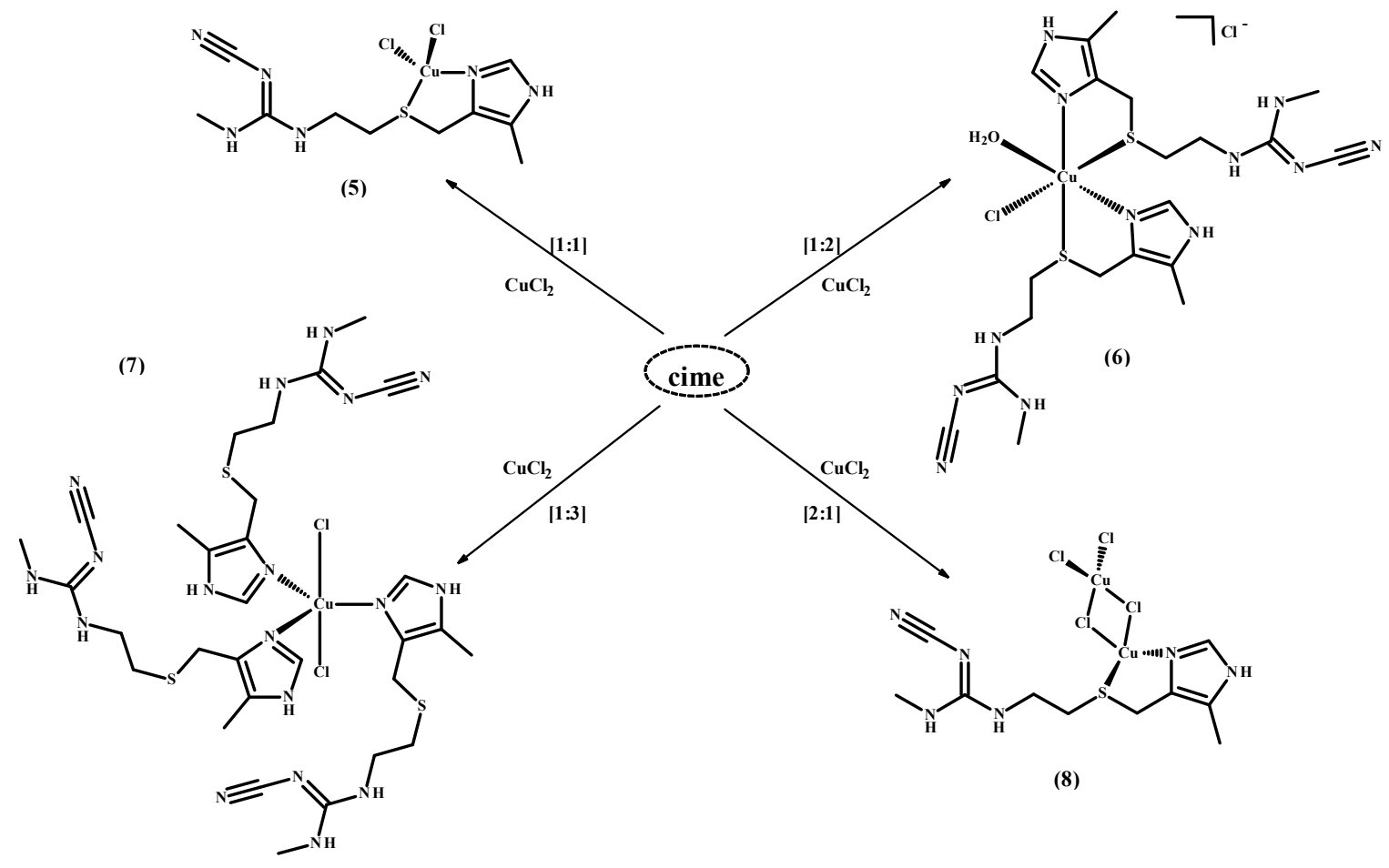

Scheme 3

\section{Spectroscopic characterization}

\section{IR and Electronic Absorption Spectra}

Table 1 shows the frequencies of the characteristic vibrations of cimetidine and its coordination compounds. The IR spectrum of cimetidine shows the following stretching vibrations $v(\mathrm{~N}-\mathrm{H})_{\text {arom }}$ at $3224, v(\mathrm{C} \equiv \mathrm{N})$ at $2176, v(\mathrm{C}=\mathrm{N})_{i m d}$ at 1587 and $v(\mathrm{C}-\mathrm{S})$ at 686 $\mathrm{cm}^{-1}$. The spectra of all complexes show the $v(\mathrm{C}=\mathrm{N})_{\text {imd }}$ vibration, shifted to higher energies for most complexes, with the exception of $\left[\mathrm{Cr}(\text { cime })_{2}(\mathrm{Cl})_{2}\right] \mathrm{Cl} \cdot 3 \mathrm{H}_{2} \mathrm{O}(\mathbf{1}),\left[\mathrm{Co}(\right.$ cime $\left.) \mathrm{Cl}_{2}\right] \cdot 5 \mathrm{H}_{2} \mathrm{O}$ (2) and $\left[\mathrm{Co}(\mathrm{cime})_{3} \mathrm{Cl}\right] \mathrm{Cl} \cdot 3 \mathrm{H}_{2} \mathrm{O}(3)$ where a shift towards lower energy was observed. These observations are indicative of coordination through the imidazolic nitrogen atom. The $v(\mathrm{C}-\mathrm{S})$ vibration was shifted to higher energy for most complexes, except for $\left[\mathrm{Co}(\text { cime })_{3} \mathrm{Cl}\right] \mathrm{Cl} \cdot 3 \mathrm{H}_{2} \mathrm{O} 3$ and $\left[\mathrm{Cu}(\text { cime })_{3} \mathrm{Cl}_{2}\right] \cdot 3 \mathrm{H}_{2} \mathrm{O}$ 7 , indicating coordination also through the thioeter sulfur atom for compounds 1, 2, $4-6,8$ and 9.

The electronic absorption spectrum (diffuse reflectance) of $\left[\mathrm{Cr}(\mathrm{cime})_{2}(\mathrm{Cl})_{2}\right] \mathrm{Cl} \cdot 3 \mathrm{H}_{2} \mathrm{O}(\mathbf{1})$ shows two bands assigned to two of the three spin allowed transitions for octahedral $\mathrm{Cr}^{\mathrm{III}}$ compounds ${ }^{4} \mathrm{~T}_{2 \mathrm{~g}} \leftarrow{ }^{4} \mathrm{~A}_{2 \mathrm{~g}}$ and ${ }^{4} \mathrm{~T}_{1 \mathrm{~g}}(\mathrm{~F}) \leftarrow{ }^{4} \mathrm{~A}_{2 \mathrm{~g}}$ at 17063 and $23666 \mathrm{~cm}^{-1}$, while those of $\left[\mathrm{Co}(\right.$ cime $\left.) \mathrm{Cl}_{2}\right] \cdot 5 \mathrm{H}_{2} \mathrm{O}(2)$ and $\left[\mathrm{Co}(\text { cime })_{3} \mathrm{Cl}\right] \mathrm{Cl} \cdot 3 \mathrm{H}_{2} \mathrm{O}$ (3) also display two bands, corresponding to the ${ }^{4} \mathrm{~T}_{1}(\mathrm{~F}) \leftarrow{ }^{4} \mathrm{~A}_{2}$ and ${ }^{4} \mathrm{~T}_{1}(\mathrm{P}) \leftarrow{ }^{4} \mathrm{~A}_{2}$ transitions for tetrahedral $\mathrm{Co}^{\mathrm{II}}\left(\mathrm{v}_{2}\right.$ and $\left.\mathrm{v}_{3}\right)$ at 7659 and 16198 , and 7843 and $17266 \mathrm{~cm}^{-1}$, respectively (see Table 2). The spectrum of $\left[\mathrm{Ni}(\right.$ cime $\left.) \mathrm{Cl}_{2}\left(\mathrm{H}_{2} \mathrm{O}\right)_{2}\right] \cdot \mathrm{H}_{2} \mathrm{O}$ (4) shows three bands at 9324,14431 and $24964 \mathrm{~cm}^{-1}$ assigned to the ${ }^{3} \mathrm{~T}_{2 \mathrm{~g}} \leftarrow{ }^{3} \mathrm{~A}_{2 \mathrm{~g}},{ }^{3} \mathrm{~T}_{1 \mathrm{~g}}(\mathrm{~F}) \leftarrow{ }^{3} \mathrm{~A}_{2 \mathrm{~g}}$ and ${ }^{3} \mathrm{~T}_{1 \mathrm{~g}}(\mathrm{P}) \leftarrow{ }^{3} \mathrm{~A}_{2 \mathrm{~g}}$

Table 1.Selected stretching vibrations $\left(\mathrm{cm}^{-1}\right)$ for cimetidine and complexes 1-9.

\begin{tabular}{|c|c|c|c|c|c|}
\hline & Compound & $v(\mathrm{C}-\mathrm{S})$ & $v(\mathrm{C}=\mathrm{N})_{\text {imd }}$ & $v(\mathrm{C} \equiv \mathrm{N})$ & $v(\mathrm{~N}-\mathrm{H})$ \\
\hline & Cimetidine & 686 & 1587 & 2176 & 3224 \\
\hline (1) & {$\left[\mathrm{Cr}(\text { cime })_{2}(\mathrm{Cl})_{2}\right] \mathrm{Cl} \cdot 3 \mathrm{H}_{2} \mathrm{O}$} & 713 & 1581 & 2211 & 3256 \\
\hline (2) & {$\left[\mathrm{Co}(\right.$ cime $\left.) \mathrm{Cl}_{2}\right] \cdot 5 \mathrm{H}_{2} \mathrm{O}$} & 713 & 1578 & 2168 & 3356 \\
\hline (3) & {$\left[\mathrm{Co}(\text { cime })_{3} \mathrm{Cl}\right] \mathrm{Cl} \cdot 3 \mathrm{H}_{2} \mathrm{O}$} & 695 & 1581 & 2202 & 3274 \\
\hline (4) & {$\left[\mathrm{Ni}(\right.$ cime $\left.) \mathrm{Cl}_{2}\left(\mathrm{H}_{2} \mathrm{O}\right)_{2}\right] \cdot \mathrm{H}_{2} \mathrm{O}$} & 715 & 1606 & 2218 & 3350 \\
\hline (5) & {$\left[\mathrm{Cu}(\right.$ cime $\left.) \mathrm{Cl}_{2}\right] \cdot 2 \mathrm{H}_{2} \mathrm{O}$} & 711 & 1596 & 2228 & 3392 \\
\hline (6) & {$\left[\mathrm{Cu}(\text { cime })_{2} \mathrm{Cl}\left(\mathrm{H}_{2} \mathrm{O}\right)\right] \mathrm{Cl} \cdot \mathrm{H}_{2} \mathrm{O}$} & 714 & 1596 & 2226 & 3392 \\
\hline (7) & {$\left[\mathrm{Cu}(\text { cime })_{3} \mathrm{Cl}_{2}\right] \cdot 3 \mathrm{H}_{2} \mathrm{O}$} & 694 & 1596 & 2226 & 3392 \\
\hline (8) & {$\left[\mathrm{Cu}_{2}(\right.$ cime $\left.) \mathrm{Cl}_{4}\right]$} & 712 & 1604 & 2215 & 3330 \\
\hline (9) & {$\left[\mathrm{Zn}(\right.$ cime $\left.) \mathrm{Cl}_{2}\right] \cdot 1.5 \mathrm{H}_{2} \mathrm{O}$} & 715 & 1586 & 2205 & 3278 \\
\hline
\end{tabular}


Table 2.Effective magnetic moment, electrical conductivity in solution and UV-Vis spectroscopyfor complexes 1-8.

\begin{tabular}{|c|c|c|c|c|c|c|}
\hline & \multirow[t]{2}{*}{ Compound } & \multirow{2}{*}{$\begin{array}{c}\mu_{\mathrm{ef}} \\
(\mathrm{MB}) \\
\end{array}$} & \multirow{2}{*}{$\frac{\mu \mathrm{S} / \mathrm{cm}}{\left(10^{-3} \mathrm{M} \mathrm{DMF}\right)}$} & \multicolumn{3}{|c|}{ UV-Vis $\left(\mathrm{cm}^{-1}\right)$} \\
\hline & & & & $v_{1}$ & $v_{2}$ & $v_{3}$ \\
\hline (1) & {$\left[\mathrm{Cr}(\text { cime })_{2}(\mathrm{Cl})_{2}\right] \mathrm{Cl} \cdot 3 \mathrm{H}_{2} \mathrm{O}$} & 3.91 & $* *$ & 17,063 & 23,666 & \\
\hline (2) & {$\left[\mathrm{Co}(\right.$ cime $\left.) \mathrm{Cl}_{2}\right] \cdot 5 \mathrm{H}_{2} \mathrm{O}$} & 4.62 & n.e. & & 7659 & 16,198 \\
\hline (3) & {$\left[\mathrm{Co}(\text { cime })_{3} \mathrm{Cl}\right] \mathrm{Cl} \cdot 3 \mathrm{H}_{2} \mathrm{O}$} & 4.76 & 71.5 & & 7843 & 17,266 \\
\hline (4) & {$\left[\mathrm{Ni}(\right.$ cime $\left.) \mathrm{Cl}_{2}\left(\mathrm{H}_{2} \mathrm{O}\right)_{2}\right] \cdot \mathrm{H}_{2} \mathrm{O}$} & 3.23 & n.e. & 9324 & 14,431 & 24,964 \\
\hline (5) & {$\left[\mathrm{Cu}(\right.$ cime $\left.) \mathrm{Cl}_{2}\right] \cdot 2 \mathrm{H}_{2} \mathrm{O}$} & 1.98 & n.e. & 13,138 & & \\
\hline (6) & {$\left[\mathrm{Cu}(\text { cime })_{2} \mathrm{Cl}\left(\mathrm{H}_{2} \mathrm{O}\right)\right] \mathrm{Cl} \cdot \mathrm{H}_{2} \mathrm{O}$} & 2.14 & 62.5 & 14,443 & & \\
\hline (7) & {$\left[\mathrm{Cu}(\text { cime })_{3} \mathrm{Cl}_{2}\right] \cdot 3 \mathrm{H}_{2} \mathrm{O}$} & 1.73 & n.e. & 14,881 & & \\
\hline (8) & {$\left[\mathrm{Cu}_{2}(\right.$ cime $\left.) \mathrm{Cl}_{4}\right]$} & 1.65 & n.e & 13,688 & & \\
\hline
\end{tabular}

$* *=$ Insoluble in common solvents, n.e. $=$ Non electrolyte.

transitions for octahedral $\mathrm{Ni}^{\mathrm{II}}$. For the $\mathrm{Cu}^{\mathrm{II}}$ compounds, the electronic absorption spectra display only one $d-d$ band in the region from 13188 to $14881 \mathrm{~cm}^{-1}$, for $\left[\mathrm{Cu}(\right.$ cime $\left.) \mathrm{Cl}_{2}\right] \cdot 2 \mathrm{H}_{2} \mathrm{O}$ (5) and $\left[\mathrm{Cu}(\right.$ cime $\left.) \mathrm{Cl}_{2}\right] \cdot 2 \mathrm{H}_{2} \mathrm{O}(\mathbf{8})$ it is assigned to the ${ }^{2} \mathrm{E} \leftarrow$ ${ }^{2} \mathrm{~T}$ transition, while for $\left[\mathrm{Cu}(\text { cime })_{2} \mathrm{Cl}\left(\mathrm{H}_{2} \mathrm{O}\right)\right] \mathrm{Cl} \cdot \mathrm{H}_{2} \mathrm{O}(6)$ to ${ }^{2} \mathrm{~T}_{2 \mathrm{~g}}$ $\leftarrow{ }^{2} \mathrm{E}_{\mathrm{g}}$ and $\left[\mathrm{Cu}(\mathrm{cime})_{3} \mathrm{Cl}_{2}\right] \cdot 3 \mathrm{H}_{2} \mathrm{O}(7)$ where a broad band is observed.

\section{NMR Data}

Table 3 shows the ${ }^{1} \mathrm{H}$ and ${ }^{13} \mathrm{C}$ and ${ }^{1} \mathrm{H}-{ }^{1} \mathrm{H}$ COSY NMR spectra were recorded in DMSO- $d_{6}$. When comparing the proton signals of the cimetidine spectrum with those in the spectrum of complex $\left[\mathrm{Zn}(\right.$ cime $\left.) \mathrm{Cl}_{2}\right] \cdot 1.5 \mathrm{H}_{2} \mathrm{O}(9)$, it is observed that they are shifted towards higher frequencies when the ligand is coordinated to $\mathrm{Zn}^{\mathrm{II}}$, especially those assigned to $\mathrm{H}-1(s)$, that is found at $11.86 \mathrm{ppm}$ for the ligand, and at $12.88 \mathrm{ppm}$ in the complex, $\mathrm{H}-2(s)$ is shifted from 7.47 to $7.95 \mathrm{ppm}$ and H-7 from 3.60 to 3.81 , indicating that the ligand is coordinated through the imidazolic nitrogen and the thioeter $\mathrm{S}$ atom.

${ }^{13} \mathrm{C}$ signals were assigned using ${ }^{1} \mathrm{H}-{ }^{13} \mathrm{C}$ HETCOR spectra. Except for C-4, the signals of the carbon atoms are displayed in the spectra of cimetidine and its zinc complex. The signals for C-2, C-5, C-6 and C-9 were shifted towards higher frequencies, when comparing to those of the free ligand. The largest shifts were for carbon atoms close to N3 and S8. The signal corresponding to $\mathrm{C}-14$ was not observed.

\section{EPR Spectra}

For $\left[\mathrm{Cr}(\text { cime })_{2}(\mathrm{Cl})_{2}\right] \mathrm{Cl} \cdot 3 \mathrm{H}_{2} \mathrm{O}$ (1), in frozen DMSO solution at $77 \mathrm{~K}$, an axially distorted EPR spectrum is obtained. The $\mathrm{g}$ value of 1.98 is typical for $\mathrm{Cr}^{\mathrm{III}}$ compounds [27].

Several complexes of $\mathrm{Cu}^{\mathrm{II}}$ are reported in the literature, obtained under different reaction conditions [1]. In addition, the structure of the copper cimetidine complex is likely to be an important factor for its biological activity [28]. For example, the anti-tumor activity of the monomeric $\mathrm{Cu}^{\mathrm{II}}$ aspirin complex $\left(\left[\mathrm{Cu}(\mathrm{Asp})_{2}(\mathrm{Py})_{2}\right]\right)$ is reportedly more effective than the dimeric $\left[\mathrm{Cu}_{2}(\mathrm{Asp})_{4}\right]$ complex [29]. The magnetic properties of $\mathrm{Cu}$ allow, therefore, the application of a range of analytical techniques to assist in the characterization of the coordina-
Table 3. Selected $\delta$ (ppm, DMSO- $d_{6}$ at $25{ }^{\circ} \mathrm{C}$ ) ${ }^{13} \mathrm{C}$ and ${ }^{1} \mathrm{H}$ NMR for cimetidine and $\left[\mathrm{Zn}(\right.$ cime $\left.) \mathrm{Cl}_{2}\right] \cdot 1.5 \mathrm{H}_{2} \mathrm{O}(9)$.

\begin{tabular}{cccccccccc}
\hline$\delta^{1} \mathrm{H}$ & $\mathrm{H} 1$ & $\mathrm{H} 2$ & $\mathrm{H} 6$ & $\mathrm{H} 7$ & $\mathrm{H} 9$ & $\mathrm{H} 10$ & $\mathrm{H} 11$ & $\mathrm{H} 17$ & \\
\hline cime & 11.86 & 7.47 & 2.13 & 3.60 & 2.55 & 3.28 & 7.18 & 2.69 & \\
$(\mathbf{9})$ & 12.88 & 7.95 & 2.18 & 3.81 & 2.53 & 3.24 & 7.16 & 2.66 & \\
$\delta^{13} \mathrm{C}$ & $\mathrm{C} 2$ & $\mathrm{C} 4$ & $\mathrm{C} 5$ & $\mathrm{C} 6$ & $\mathrm{C} 7$ & $\mathrm{C} 9$ & $\mathrm{C} 10$ & $\mathrm{C} 12$ & $\mathrm{C} 17$ \\
cime & 133.4 & 122.1 & 118.2 & 9.2 & 26.2 & 29.9 & 40.8 & 159.9 & 28.3 \\
$(\mathbf{9})$ & 135.2 & 127.1 & 117.8 & 9.8 & 24.5 & 30.6 & 40.6 & 159.9 & 28.1 \\
\hline
\end{tabular}

tion around the $\mathrm{Cu}^{\mathrm{II}}$ center. Thus, here the EPR spectra of the mononuclear $\mathrm{Cu}^{\mathrm{II}}$ complexes $\left[\mathrm{Cu}(\right.$ cime $\left.)(\mathrm{Cl})_{2}\right] \cdot 2 \mathrm{H}_{2} \mathrm{O}(\mathbf{5})$, $\left[\mathrm{Cu}(\text { cime })_{2} \mathrm{Cl}\left(\mathrm{H}_{2} \mathrm{O}\right)\right] \mathrm{Cl} \cdot \mathrm{H}_{2} \mathrm{O}(6)$ and $\left[\mathrm{Cu}(\text { cime })_{3} \mathrm{Cl}_{2}\right] \cdot 3 \mathrm{H}_{2} \mathrm{O}(7)$ are discussed. For complex (5), the X-band EPR spectrum of a powder sample obtained at room temperature shows a rhombic signal with the following g- values; $\mathrm{g}_{1}=2.232, \mathrm{~g}_{2}=2.116 \mathrm{y} \mathrm{g}_{3}=$ 2.019 with $g_{\text {aver }}$ - value of 2.122 , see Table 4 . This complex in frozen DMSO solution at $77 \mathrm{~K}$ shows an axial -type EPR spectrum with $\mathrm{g}_{\perp}=2.086$ and $\mathrm{g}_{\|}=2.344$ ( $\mathrm{g}_{\text {aver }}$ - value of 2.172) and hyperfine splitting in the parallel component with $\mathrm{a}_{\|}^{\mathrm{Cu}}=142.1$ $\mathrm{G}$, see Fig. 1. This change in the $\mathrm{g}_{\mathrm{aver}}$ - value suggests modification of the compound geometry from distorted tetrahedral in the solid state, while in solution an octahedral environment is favored [30].

S.-Garcia and coworkers [31] studied the stability of the copper(II) ions complexed with cimetidine in aqueous solutions observing a sharp increase in the absorbance in $2 \mathrm{~min}$, afterwards it remained constant for at least $1 \mathrm{~h}$. This observation indicates changes in the environment around the transition metal ion in solution. Additionally, this spectrum is similar to that reported by Hinojosa [32] of the [Cu(cime)L-Ala $(\mathrm{OH})\left(\mathrm{H}_{2} 0\right)$ ] complex where a dimeric nature for the latter compound was proposed. In our case, no characteristic signal of dimeric species around $1700 \mathrm{G}$ is observed.

On the other hand, for $\left[\mathrm{Cu}(\text { cime })_{2} \mathrm{Cl}\left(\mathrm{H}_{2} \mathrm{O}\right)\right] \mathrm{Cl} \cdot \mathrm{H}_{2} \mathrm{O}$ (6), the EPR spectrum at room temperature of a powder sample, see Fig. 2, shows a rhombic signal with g-values; $g_{1}=2.224$, $\mathrm{g}_{2}=2.114, \mathrm{~g}_{3}=2.027$ with a $\mathrm{g}_{\text {aver-value of }} 2.121$ corresponding to a $\mathrm{Cu}^{\mathrm{II}}$ in a distorted octahedral geometry [30]. In frozen 
Table 4.Best fit EPR spectroscopic parameters of complexes.

\begin{tabular}{|c|c|c|c|c|c|c|c|}
\hline \multirow[t]{2}{*}{ Compound } & \multicolumn{4}{|c|}{ Solid sample } & \multicolumn{3}{|c|}{ Frozen solution $(77 \mathrm{~K})$} \\
\hline & $g_{1}$ & $\mathrm{~g}_{2}$ & $\mathrm{~g}_{3}$ & $g_{\text {aver }}$ & $\mathrm{g}_{\|}$ & $\mathrm{g}_{\perp}^{\mathrm{a}}$ & $\mathrm{g}_{\text {aver }}$ \\
\hline$\left[\mathrm{Cr}(\text { cime })_{2}(\mathrm{Cl})_{2}\right] \mathrm{Cl} \cdot 3 \mathrm{H}_{2} \mathrm{O}(\mathbf{1})$ & & & & & & $1.98^{\mathrm{b}}$ & 1.98 \\
\hline$\left[\mathrm{Cu}(\right.$ cime $\left.)(\mathrm{Cl})_{2}\right] \cdot 2 \mathrm{H}_{2} \mathrm{O}(\mathbf{5})$ & 2.232 & 2.116 & 2.019 & 2.122 & $\begin{array}{l}2.086 \\
(142)\end{array}$ & 2.344 & 2.172 \\
\hline$\left[\mathrm{Cu}(\text { cime })_{2} \mathrm{Cl}\left(\mathrm{H}_{2} \mathrm{O}\right)\right] \mathrm{Cl} \cdot \mathrm{H}_{2} \mathrm{O}(\mathbf{6})$ & 2.224 & 2.114 & 2.027 & 2.121 & $\begin{array}{l}2.342 \\
(134)\end{array}$ & 2.0782 & 2.166 \\
\hline$\left[\mathrm{Cu}(\text { cime })_{3} \mathrm{Cl}_{2}\right] \cdot 3 \mathrm{H}_{2} \mathrm{O}(7)$ & & $2.088^{b}$ & & 2.088 & $\begin{array}{l}2.249 \\
(113)\end{array}$ & 2.072 & 2.156 \\
\hline$\left[\mathrm{Cu}(\text { cime })_{2}\right]\left(\mathrm{ClO}_{4}\right)_{2}{ }^{\mathrm{c}}$ & & 2.08 & 2.04 & 2.05 & & & \\
\hline$\left[\mathrm{Cu}(\text { cime })_{2}\right]\left(\mathrm{ClO}_{4}\right)_{2}{ }^{\mathrm{d}}$ & & & & & 2.332 & $\begin{array}{l}2.078 \\
(147)^{\mathrm{f}}\end{array}$ & 2.163 \\
\hline$[\mathrm{Cu}($ cime $) \mathrm{L}-\mathrm{Ala}] \mathrm{B}\left(\mathrm{C}_{6} \mathrm{H}_{5}\right)_{4}{ }^{\mathrm{e}}$ & & $\begin{array}{c}2.30 \\
(223)^{\mathrm{f}}\end{array}$ & 2.09 & 2.16 & & & \\
\hline$[\mathrm{Cu}($ cime $) \mathrm{L}-\mathrm{Ala}(\mathrm{OH})] \mathrm{H}_{2} \mathrm{O}^{\mathrm{e}}$ & 2.46 & 2.10 & 1.90 & 2.15 & & & \\
\hline
\end{tabular}

${ }^{\mathrm{a}} \mathrm{a}_{\|}^{\mathrm{Cu}}(\mathrm{G})$; bisotropic signal; ' ${ }^{2}$ Sancho (1985); ${ }^{\mathrm{d}}$ at $90 \mathrm{~K}$ in frozen aqueous (pH 5.8)solutions.

Greenaway (1980); ${ }^{\mathrm{e}}$ Hinojosa (1987); ${ }^{\mathrm{f}} \times 10^{-4} \mathrm{~cm}^{-1}$

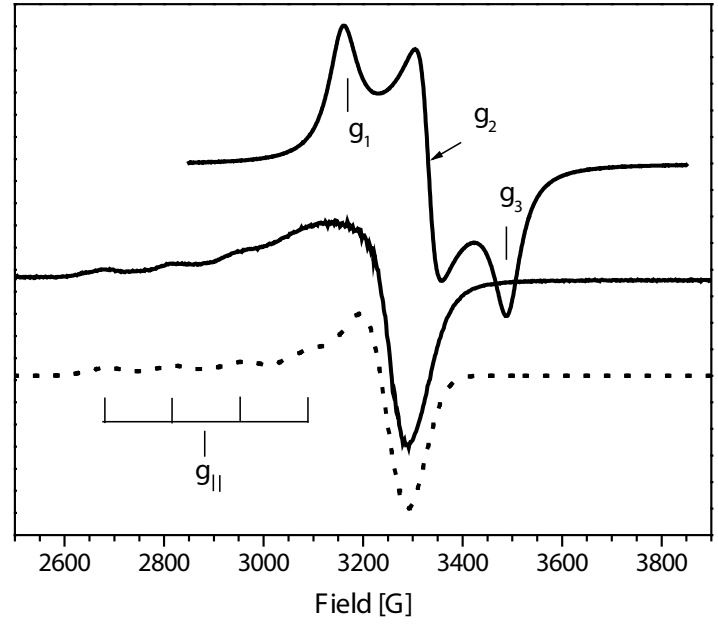

Fig. 1. X-band EPR spectrum of $\left[\mathrm{Cu}(\right.$ cime $\left.) \mathrm{Cl}_{2}\right] \cdot 2 \mathrm{H}_{2} \mathrm{O}$ (5), powder sample at room temperature (upper), in frozen DMSO solution at 77 $\mathrm{K}$ (middle) and simulated (dotted spectrum). Experimental conditions: microwave frequency, $9.34266 \mathrm{GHz}$; microwave power, $2.0 \mathrm{~mW}$; modulation amplitude: $0.3 \mathrm{mT}$.

(0.1 M, DMF) solution at $77 \mathrm{~K}$ an axial signal was obtained with the following g-values; $\mathrm{g}_{\|}=2.342$ and $\mathrm{g}_{\perp}=2.078$ with hyperfine $\left(\mathrm{a}_{\|}^{\mathrm{Cu}}=134 \mathrm{G}\right)$ splitting. the $\mathrm{g}_{\mathrm{aver}}$-value of 2.166 different from that obtained for the powder sample, this again suggests changes in the environment around the $\mathrm{Cu}^{\mathrm{II}}$ metal center (Table 4).

In this case, Sancho and coworkers [33] reported the EPR spectrum for $\left[\mathrm{Cu}(\text { cime })_{2}\right]\left(\mathrm{ClO}_{4}\right)_{2}$ in the solid state, according to the g-values observed, a $\mathrm{Cu}^{\mathrm{II}}$ center in an elongated tetragonal octahedral environment is suggested. However, both Sancho and Greenaway [4] found by X-ray analysis that this complex is formed by an infinite cationic polymer and the perchlorate ions are linked by $\mathrm{N}-\mathrm{H} \cdots \mathrm{O}$, hydrogen bonds.

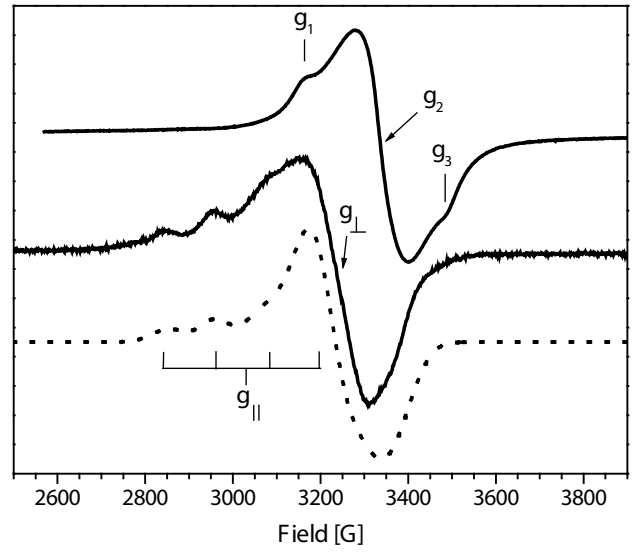

Fig. 2. X-band EPR spectrum of $\left[\mathrm{Cu}(\text { cime })_{2}(\mathrm{Cl})\left(\mathrm{H}_{2} \mathrm{O}\right)\right] \mathrm{Cl} \cdot \mathrm{H}_{2} \mathrm{O}(\mathbf{6})$, powder sample (upper), in frozen DMSO solution at $77 \mathrm{~K}$ (middle) and simulated (dotted spectrum). Experimental conditions: microwave frequency, $9.34266 \mathrm{GHz}$; microwave power, $2.0 \mathrm{~mW}$; modulation amplitude: $0.3 \mathrm{mT}$.

For complex (7), from a powder sample, its EPR spectrum obtained at room temperature shows a pseudo-isotropic signal with g-value of 2.088 while in a frozen DMF solution at $77 \mathrm{~K}$ shows a EPR spectrum an axially-distorted signal with $\mathrm{g}_{\text {aver }}$ - value of $2.156\left(\mathrm{~g}_{\|}=2.249\right.$ and $\left.\mathrm{g}_{\perp}=2.072\right)$ and hyperfine splitting in the parallel component $\left(\mathrm{a}_{\|}^{\mathrm{Cu}}=113 \mathrm{G}\right)$, see Fig. 3 and Table 4. These type of EPR spectra are typical of distorted octahedral $\mathrm{Cu}^{\mathrm{II}}$ compounds for the solution sample, where DMF must be coordinated to the $\mathrm{Cu}$ centre [28].

\section{Magnetic susceptibility and electrical conductivity}

The effective magnetic moments observed for compounds 1 to 8 are within the expected values for $\mathrm{Cr}^{\mathrm{III}}(\mathbf{1}), \mathrm{Co}^{\mathrm{II}}(\mathbf{2}, \mathbf{3}), \mathrm{Ni}^{\mathrm{II}}$ (4) and $\mathrm{Cu}^{\mathrm{II}}(5-\mathbf{8})$, with three, two and one unpaired electrons. 


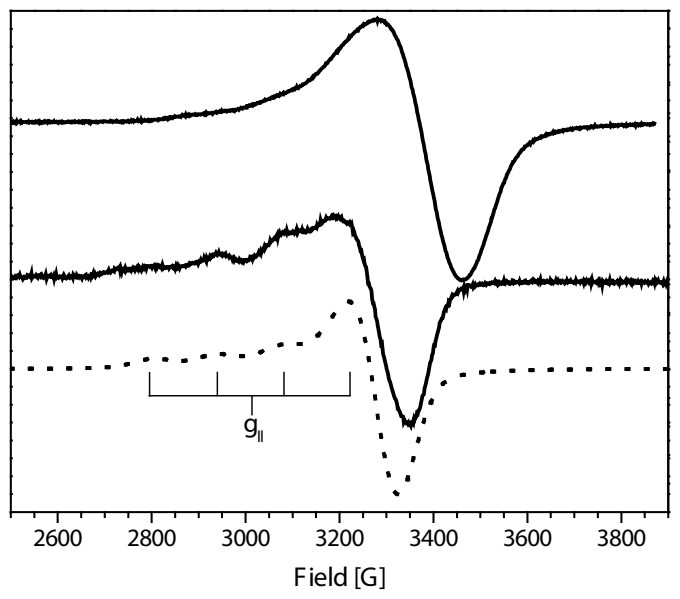

Fig. 3. Experimental and simulated (dotted spectrum) X-band EPR spectrum for $\left[\mathrm{Cu}(\text { cime })_{3} \mathrm{Cl}_{2}\right] \cdot 3 \mathrm{H}_{2} \mathrm{O}$ (7) in (upper) powder sample at room temperature in (middle) frozen DMSO solution at $77 \mathrm{~K}$. Experimental conditions: microwave frequency, $9.34266 \mathrm{GHz}$; microwave power, $2.0 \mathrm{~mW}$; modulation amplitude: $0.3 \mathrm{mT}$.

Their molar conductivities measured in DMF are characteristic for 1:1 (3 and 6) electrolytes (see Table 2).

\section{Structural analyses by DFT calculations}

Electrostatic potential maps of three-dimensional molecular diagrams are very useful. They enable us to visualize the charge distribution in the molecules and predict their properties and reactivity; and also allow us to picture the size and shape of molecules.

We calculated the electron density and electrostatic potential map of cimetidine in order to identify its most reactive areas, (see Fig. 4), the red areas are rich in electron density, while those in blue show the areas with low electron density. Although the cyano group is rich in electron density is not coordinating and all hydrogen atoms that are attached to the nitrogen atoms occur on blue zones, that is in electron deficient zones, therefore it was inferred that the coordinating sites of the molecule are the imidazolic nitrogen and the thioeter sulfur. This is consistent with the results presented here in and other reports [4-6, 10-12].

An important aim of this work is the structural analysis of the different complexes and the stabilization evaluation of the different geometries and point groups. The structures of minimum energy were determined by calculating their vibrational modes; all stationary points are true minimal. The calculated results agree with those from the IR and UV-Vis spectroscopic data of the herein synthesized compounds.

The analysis of all possible geometries for compounds $\mathbf{1}$ - 9, by changing the orientation of the bidentate ligands to find out the global minimum, resulted in various symmetries: $C_{1}$ for $\mathbf{2}, \mathbf{4}, \mathbf{5}, \mathbf{6}, \mathbf{8}$ and $\mathbf{9} ; C_{2}$ for $\mathbf{1}$ and $C_{3}$ for $\mathbf{3}$ and $\mathbf{7}$. These were the most stable symmetries for the coordination compounds. Figures 5 and 6 show the most stable structures calculated by the B3LYP/def2-TZVP method. Tetra- and hexacoordinated

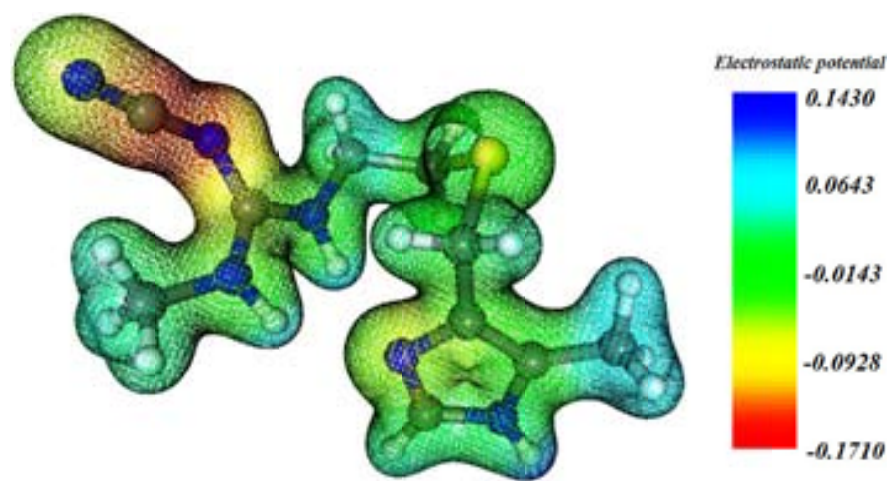

Fig. 4. Electrostatic potential map for the cimetidine.

compounds may stabilize either distorted tetrahedral or octahedral geometries, respectively.

The lowest energy optimized structures of complexes $\mathbf{1}$ and $6\left(C_{2}\right.$ and $C_{1}$ symmetries, respectively), show a preference for inter- ligand interaction of two ligands in the same molecule, between the nitrogen atom of the cyano group and the hydrogen atom of imidazole $\mathrm{NH}$, where the sum of the van der Waals radii $\mathrm{N} \bullet \bullet \mathrm{H}(2.8 \AA)$ are smaller than those calculated using literature data [34], (see Fig. 5). This interaction stabilizes the "U" intra- ligand arrangement for $C_{1}$ symmetry compounds $\mathbf{2}$, 5, 8 and 9, see Figure 6. These interactions may be of outmost importance in determining the geometry of the complexes.

According to the calculations trans isomer is the most stable for compounds 1 and 4 : $\left[\mathrm{Cr}(\text { cime })_{2} \mathrm{Cl}_{2}\right] \mathrm{Cl} \cdot 3 \mathrm{H}_{2} \mathrm{O}$, $\left[\mathrm{Ni}(\right.$ cime $\left.) \mathrm{Cl}_{2}\left(\mathrm{H}_{2} \mathrm{O}\right)_{2}\right] \cdot \mathrm{H}_{2} \mathrm{O}$ while for $\mathbf{6}$, $\left[\mathrm{Cu}(\text { cime })_{2} \mathrm{Cl}\left(\mathrm{H}_{2} \mathrm{O}\right)\right] \mathrm{Cl}$. $\mathrm{H}_{2} \mathrm{O}$, the cis isomer results more stable than the trans. For compound $7,\left[\mathrm{Cu}(\text { cime })_{3} \mathrm{Cl}_{2}\right] \cdot 3 \mathrm{H}_{2} \mathrm{O}$, the DFT calculations indicate that its geometry is TBP

The geometries of copper(II) complexes is either distorted octahedral, distorted tetrahedral or distorted TBP, as expected.

\section{Concluding Remarks}

Cimetidine coordinated in most cases as a bidentate ligand, except when three ligands coordinated to the metal ion, where coordination only through the imidazolic nitrogen atom was observed. Four different copper(II) compounds were isolated when the reactions were carried out at different molar ratios, yielding tetrahedral and octahedral complexes. EPR spectra and DFT calculations support the results presented herein.

This contribution includes the synthesis and characterisation of cimetidine complexes with the chlorides of chromium(III), cobalt(II), nickel(II), copper(II) and zinc(II), where spectroscopic and analytical data allow us to propose different structures for the compounds. These proposed structures are in agreement with the spectroscopic and MS data.

Cimetidine acts as bidentate ligand, since hydrogen bonds are formed between the cyano group of a coordinated molecule with the uncoordinated $\mathrm{NH}$ of the imidazole, belonging to a second coordinated cimetidine molecule. 

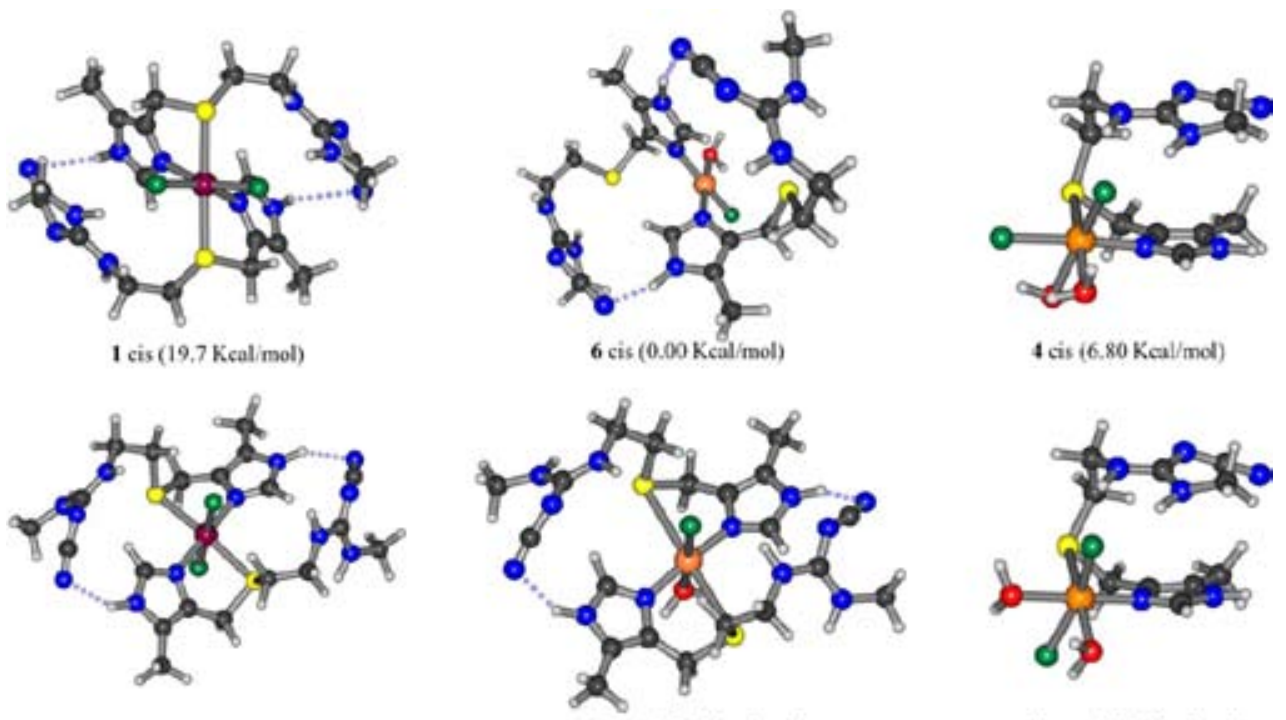

$4 \mathrm{cis}(6.80 \mathrm{Kcal} / \mathrm{mol})$

1 trans $(0.00 \mathrm{Kcal} / \mathrm{mol})$

6 trans $(0.78 \mathrm{Kcal} / \mathrm{mol})$

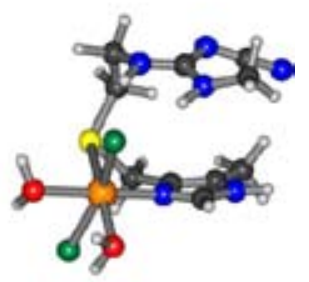

4 trans $(0.00 \mathrm{Kcal} / \mathrm{mol})$

Fig. 5. Conformation cis and trans calculated for $\mathbf{1}, \mathbf{4}$ and $\mathbf{6}$ using the method B3LYP/def2-TZVP. Representation of the van der Waals interaction $[\mathrm{N} \cdots \mathrm{H}]$, for 1 and $\mathbf{6}$.
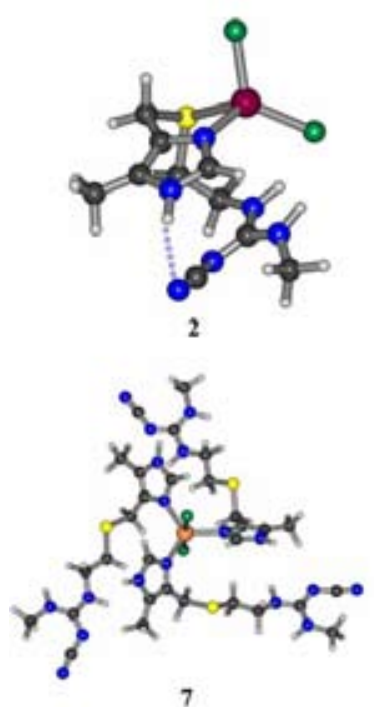

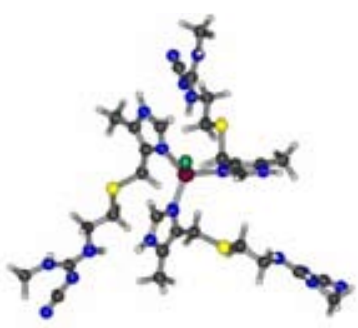

3

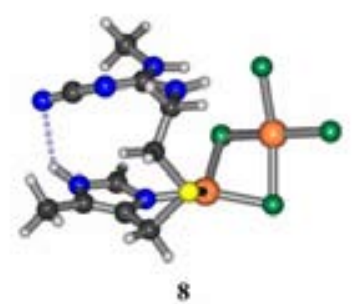

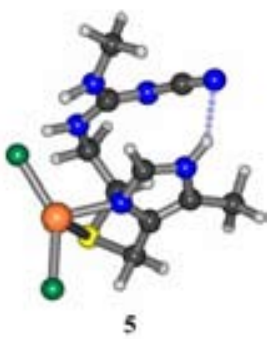

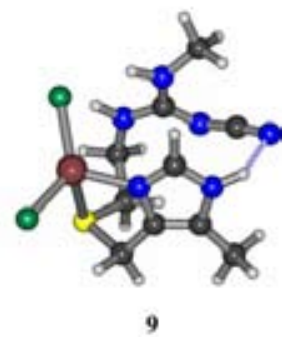

Fig. 6. Structures calculated for 2, 3, 5 and 7-9 using the method B3LYP/def2-TZVP. Representation of the van der Waals interaction [N॰.•H], for $2,5,8$ and 9.

Antiulcer activity of the copper(II) compounds is to be tested in a near future.

\section{Experimental}

\section{Materials}

Metal salts and solvents were purchased from Aldrich, Fluka or Baker (absolute ethanol) and used without further purification.

Cimetidine (was kindly provided by ENCB-IPN, México), Elemental analysis calculated for $\mathrm{C}_{10} \mathrm{H}_{16} \mathrm{~N}_{6} \mathrm{~S}, \mathrm{C} 47.60, \mathrm{H} 6.39$, N 33.30, S 12.71; Found C 47.64, H 6.41, N 33.68, S 12.88\%.
IR, $\left(v, \mathrm{~cm}^{-1}\right)(\mathrm{N}-\mathrm{H})($ arom $) 3224,(\mathrm{C}-\mathrm{NH}) 3143,\left(\mathrm{C}-\mathrm{NH}-\mathrm{CH}_{3}\right)$ 3036, $\left(\mathrm{CH}_{3}\right)$ 2920, $(\mathrm{C} \equiv \mathrm{N})$ 2176, (C=C-) 1621, $(\mathrm{C}=\mathrm{N})$ 1587, $\left(\mathrm{CH}_{3}\right)$ 1386, (C-S-) 686. NMR $\left(\delta \mathrm{ppm}, \mathrm{DMSO}-d_{6}\right){ }^{1} \mathrm{H}: \mathrm{H} 1(\mathrm{~s}$, 11.86), H2 (s, 7.47), H6 (s, 2.13), H7 (s, 3.60), H9 (t, 2.55), $\mathrm{H} 10$ (dd, 3.28), H11 (s, 7.18), H16 (s, 7.30$) \mathrm{H} 17$ (d, 2.69); ${ }^{13} \mathrm{C}$ NMR ( $\delta$ ppm, DMSO- $d_{6}$ ) C2 133.4, C4 122.1, C5 118.2, C6 9.2, C7 26.2, C9 29.9, C10 40.8, C12 159.9, C17 28.3.

\section{Physical Methods}

IR spectra were recorded on $\mathrm{KBr}$ pellets on a Perkin Elmer FTIR model 1605 spectrometer from 4000 to $400 \mathrm{~cm}^{-1}$. Elemental Analyses were obtained on a Fisons Instruments model 
EA1108 analyses, using sulphanilamide as standard. Diffuse reflectance UV-Vis-NIR electronic absorption spectra were determined on a Varian Cary 5E spectrometer, from 40000 to $4000 \mathrm{~cm}^{-1}$. A Johnson Mathey MSB model MK II magnetic balance was used to determine the magnetic susceptibility of the samples. ${ }^{1} \mathrm{H},{ }^{13} \mathrm{C},{ }^{1} \mathrm{H}-{ }^{1} \mathrm{H}$ COSY and ${ }^{1} \mathrm{H}-{ }^{13} \mathrm{C}$ HETCOR NMR spectra were obtained on a Varian Unity Inova (400 MHz) in DMSO- $d_{6}$.

The EPR spectra were obtained on Brucker Elexsys E500 spectrometer, both in solid state at room temperature as in frozen DMSO and DMF solution at $77 \mathrm{~K}$ using conventional finger dewar. EPR spectra were evaluated and simulated using the Bruker software, and g-values were calculated by measuring accurately the magnetic field and the microwave frequency. Electrical conductivity was determined from $10^{-3} \mathrm{M}$ DMSO solutions using an ORION 140 conductimeter.

\section{Synthesis}

$\left[\mathrm{Cr}(\text { cime })_{2}(\mathrm{Cl})_{2}\right] \mathrm{Cl} \cdot 3 \mathrm{H}_{2} \mathrm{O}$, (1). $200 \mathrm{mg}$ of granular $\mathrm{Zn}^{0}$ were treated with conc. $\mathrm{HCl}$ and transferred to a filter thimble of a Soxhlet extractor together with $5 \mathrm{~g}$ of cimetidine and 758 mg of anhydrous $\mathrm{CrCl}_{3} .40 \mathrm{~mL}$ of methanol were added to the reservoir flask and the methanol was refluxed for $30 \mathrm{~min}-$ utes. The chromium chloride and cimetidine were extracted and after evaporating the solvent a green paste was obtained. This was washed with ethanol and a green precipitate was isolated, yield $38 \%(807.7 \mathrm{mg})$. Elemental analysis calculated for $\mathrm{C}_{20} \mathrm{H}_{38} \mathrm{O}_{3} \mathrm{~N}_{12} \mathrm{~S}_{2} \mathrm{Cl}_{3} \mathrm{Cr}$, C 33.50, H 5.34, N 23.44, S 8.94; Found C 33.62, H 5.51, N 21.89, S 8.33\%.

$\left[\mathrm{Co}\right.$ (cime) $\left.\mathrm{Cl}_{2}\right] \cdot 5 \mathrm{H}_{2} \mathrm{O}, \quad(2) .0 .5 \mathrm{mmol}(118.9 \mathrm{mg})$ of $\mathrm{CoCl}_{2} \cdot 6 \mathrm{H}_{2} \mathrm{O}$ and $0.5 \mathrm{mmol}(126.1 \mathrm{mg})$ of cimetidine, were separately dissolved in ethanol $(15 \mathrm{~mL})$, then mixed and refluxed for $24 \mathrm{~h}$, yielding a blue solution which was concentrated and left for two days yielding a dark blue precipitate, yield 35\% (82.7 mg). Elemental analysis calculated for $\mathrm{C}_{10} \mathrm{H}_{26} \mathrm{O}_{5} \mathrm{~N}_{6} \mathrm{SCo}, \mathrm{C}$ 25.43, H 5.54, N 17.79, S 6.79; Found C 25.53, H 4.68, N 17.04, $\mathrm{S} 7.62 \%$. EM $\left(\mathrm{FAB}^{+}\right),\left(\mathrm{m} / \mathrm{z}\right.$, fragment) $346[\mathrm{Co}(\mathrm{cime}) \mathrm{Cl}]^{+}, 155$ $[\mathrm{Co}(\text { cime })]^{2+}$.

$\left[\mathrm{Co}(\right.$ cime $\left.){ }_{3} \mathrm{Cl}\right] \mathrm{Cl} \cdot 3 \mathrm{H}_{2} \mathrm{O},(3) .0 .5 \mathrm{mmol}(118.9 \mathrm{mg})$ of $\mathrm{CoCl}_{2} \cdot 6 \mathrm{H}_{2} \mathrm{O}$ and $1.5 \mathrm{mmol}(378.4 \mathrm{mg}$ ) of cimetidine, were separately dissolved in ethanol $(15 \mathrm{~mL})$, then mixed and refluxed for $24 \mathrm{~h}$, yielding a blue solution which was left to stand for two days and a blue solid was isolated, yield $27 \%(127.0 \mathrm{mg})$. Elemental analysis calculated for $\mathrm{C}_{30} \mathrm{H}_{54} \mathrm{O}_{3} \mathrm{~N}_{18} \mathrm{~S}_{3} \mathrm{Cl}_{2} \mathrm{Co}$, C 38.30, H 5.78, N 26.79, S 10.22; Found C 38.72, H 5.56, N 26.11, S $11.04 \%$. EM $\left(\mathrm{FAB}^{+}\right),\left(\mathrm{m} / \mathrm{z}\right.$, fragment) $850\left[\mathrm{Co}(\mathrm{cime}){ }_{3} \mathrm{Cl}\right]^{+}, 598$ $\left[\mathrm{Co}(\text { cime })_{2} \mathrm{Cl}\right]^{+}, 346[\mathrm{Co}(\mathrm{cime}) \mathrm{Cl}]^{+}, 155[\mathrm{Co}(\text { cime })]^{2+}$.

$\left[\mathrm{Ni}(\mathrm{cime}) \mathrm{Cl}_{2}\left(\mathrm{H}_{2} \mathrm{O}\right)_{2}\right] \cdot \mathrm{H}_{2} \mathrm{O}$, (4). $118 \mathrm{mg}(0.5 \mathrm{mmol})$ of $\mathrm{NiCl}_{2} \cdot 6 \mathrm{H}_{2} \mathrm{O}$ was dissolved in $15 \mathrm{~mL}$ of ethanol, and mixed with a solution of $126.1 \mathrm{mg}(0.5 \mathrm{mmol})$ of cimetidine in $15 \mathrm{~mL}$ of ethanol. The mixture was stirred for $24 \mathrm{~h}$ and a light green precipitate was isolated and washed with ethanol, yield 51\% (111.1 $\mathrm{mg}$ ). Elemental analysis calculated for $\mathrm{C}_{10} \mathrm{H}_{22} \mathrm{O}_{3} \mathrm{~N}_{6} \mathrm{SCl}_{2} \mathrm{Ni}, \mathrm{C}$ 27.65, H 5.07, N 19.35, S 7.37; Found C 27.67, H 5.28, N 18.55, $\mathrm{S} 6.91 \%$. EM $\left(\mathrm{FAB}^{+}\right),\left(\mathrm{m} / \mathrm{z}\right.$, fragment) $345[\mathrm{Ni}(\mathrm{cime}) \mathrm{Cl}]^{+}, 155$
$[\mathrm{Ni}(\text { cime })]^{2+}$.

$\left[\mathrm{Cu}\right.$ (cime) $\left.\mathrm{Cl}_{2}\right] \cdot 2 \mathrm{H}_{2} \mathrm{O}, \quad$ (5). $84.4 \mathrm{mg}(0.5 \mathrm{mmol})$ of $\mathrm{CuCl}_{2} \cdot 2 \mathrm{H}_{2} \mathrm{O}$ were dissolved in $15 \mathrm{~mL}$ of etanol, and mixed with $15 \mathrm{~mL}$ of a cimetidine ethanolic solution $(126.1 \mathrm{mg}, 0.5$ $\mathrm{mmol}$ ). The mixture was stirred for $24 \mathrm{~h}$ and a green precipitate was isolated and washed with ethanol, yield $85 \%(179.7 \mathrm{mg})$. Elemental analysis calculated for $\mathrm{C}_{10} \mathrm{H}_{20} \mathrm{O}_{2} \mathrm{~N}_{6} \mathrm{SCl}_{2} \mathrm{Cu}, \mathrm{C} 28.50$, H 4.75, N 19.95, S 7.60; Found C 28.91, H 4.68, N 19.75, S $8.14 \%$. EM $\left(\mathrm{FAB}^{+}\right),\left(\mathrm{m} / \mathrm{z}\right.$, fragment) $350[\mathrm{Cu}(\mathrm{cime}) \mathrm{Cl}]^{+}, 158$ $[\mathrm{Cu}(\text { cime })]^{2+}$.

$\left[\mathrm{Cu}\right.$ (cime) $\left.{ }_{2} \mathrm{Cl}\left(\mathrm{H}_{2} \mathrm{O}\right)\right] \mathrm{Cl} \cdot \mathrm{H}_{2} \mathrm{O}$, (6). $84.4 \mathrm{mg}(0.5 \mathrm{mmol})$ of $\mathrm{CuCl}_{2} \cdot 2 \mathrm{H}_{2} \mathrm{O}$ were dissolved in $15 \mathrm{~mL}$ of ethanol, and mixed with $15 \mathrm{~mL}$ of a cimetidine ethanolic solution $(252.3 \mathrm{mg}, 1.0$ $\mathrm{mmol}$ ). The mixture was stirred for $24 \mathrm{~h}$ and a green precipitate was isolated and washed with ethanol, yield 79\% (266.6 $\mathrm{mg}$ ). Elemental analysis calculated for $\mathrm{C}_{20} \mathrm{H}_{36} \mathrm{O}_{2} \mathrm{~N}_{12} \mathrm{~S}_{2} \mathrm{Cl}_{2} \mathrm{Cu}, \mathrm{C}$ 35.66, H 5.35, N 24.96, S 9.51; Found C 34.97, H 5.10, N 24.07, $\mathrm{S} 9.94 \%$. EM $\left(\mathrm{FAB}^{+}\right),(\mathrm{m} / \mathrm{z}$, fragment $) 602\left[\mathrm{Cu}(\mathrm{cime}){ }_{2} \mathrm{Cl}\right]^{+}, 350$ $[\mathrm{Cu}(\text { cime }) \mathrm{Cl}]^{+}, 284\left[\mathrm{Cu}(\text { cime })_{2}\right]^{2+}, 158[\mathrm{Cu}(\text { cime })]^{2+}$.

$\left[\mathrm{Cu}(\text { cime })_{3} \mathrm{Cl}_{2}\left(\mathrm{H}_{2} \mathrm{O}\right)\right] \cdot 2 \mathrm{H}_{2} \mathrm{O}$, (7). $84.4 \mathrm{mg}(0.5 \mathrm{mmol})$ of $\mathrm{CuCl}_{2} \cdot 2 \mathrm{H}_{2} \mathrm{O}$ were dissolved in $15 \mathrm{~mL}$ of ethanol, and mixed with $15 \mathrm{~mL}$ of a cimetidine ethanolic solution $(378.4 \mathrm{mg}, 1.5$ $\mathrm{mmol}$ ). The mixture was stirred for $24 \mathrm{~h}$ and a green precipitate was isolated and washed with etanol, yield $53 \%(250.6 \mathrm{mg})$. Elemental analysis calculated for $\mathrm{C}_{30} \mathrm{H}_{54} \mathrm{O}_{3} \mathrm{~N}_{18} \mathrm{~S}_{3} \mathrm{Cl}_{2} \mathrm{Cu}, \mathrm{C} 38.18$, H 5.73, N 26.72, S 10.19; Found C 37.76, H 5.48, N 25.93, S $10.87 \%$. EM $\left(\mathrm{FAB}^{+}\right),(\mathrm{m} / \mathrm{z}$, fragment $) 602\left[\mathrm{Cu}(\mathrm{cime})_{2} \mathrm{Cl}\right]^{+}, 410$ $\left[\mathrm{Cu}(\text { cime })_{3}\right]^{2+}, 284\left[\mathrm{Cu}(\text { cime })_{2}\right]^{2+}, 158[\mathrm{Cu}(\text { cime })]^{2+}$.

$\left[\mathrm{Cu}_{2}\right.$ (cime) $\left.\mathrm{Cl}_{4}\right],(8) .168 .8 \mathrm{mg}(1.0 \mathrm{mmol})$ of $\mathrm{CuCl}_{2} \cdot 2 \mathrm{H}_{2} \mathrm{O}$ were dissolved in $15 \mathrm{~mL}$ of ethanol, and mixed with $15 \mathrm{~mL}$ of a cimetidine ethanolic solution $(126.1 \mathrm{mg}, 0.5 \mathrm{mmol})$. The mixture was stirred for $24 \mathrm{~h}$ and a green precipitate was isolated and washed with ethanol, yield $81 \%$ (211.1 $\mathrm{mg})$. Elemental analysis calculated for $\mathrm{C}_{10} \mathrm{H}_{16} \mathrm{~N}_{6} \mathrm{SCl}_{4} \mathrm{Cu}_{2}, \mathrm{C} 23.04, \mathrm{H} 3.1, \mathrm{~N} 16.12, \mathrm{~S}$ 6.15; Found C 23.34, H 4.27, N 15.88, S 7.05\%. EM $\left(\mathrm{FAB}^{+}\right)$, (m/z, fragment) $519\left[\mathrm{Cu}_{2}(\mathrm{cime}) \mathrm{Cl}_{4}\right]^{+}, 483\left[\mathrm{Cu}_{2}(\mathrm{cime}) \mathrm{Cl}_{3}\right]^{+}, 422$ $\left[\mathrm{Cu}(\text { cime }) \mathrm{Cl}_{3}\right]^{+}, 224\left[\mathrm{Cu}_{2}(\mathrm{cime}) \mathrm{Cl}_{2}\right]^{2+}, 138\left[\mathrm{Cu}_{2}(\mathrm{cime}) \mathrm{Cl}\right]^{3+}, 95$ $\left[\mathrm{Cu}_{2}(\mathrm{cime})\right]^{4+}$.

$\left[\mathrm{Zn}(\right.$ cime $\left.) \mathrm{Cl}_{2}\right] \cdot 1.5 \mathrm{H}_{2} \mathrm{O},(\mathbf{9}) .136 .28 \mathrm{mg}(1.0 \mathrm{mmol})$ of $\mathrm{Zn}$ $\mathrm{Cl}_{2}$ were dissolved in $15 \mathrm{~mL}$ of ethanol, and mixed with 15 $\mathrm{mL}$ of a cimetidine ethanolic solution $(252.3 \mathrm{mg}, 1.0 \mathrm{mmol})$. A precipitate was isolated and washed with ethanol, yield $89 \%$ (369.3 mg). NMR ( $\delta$ ppm, DMSO- $\left.d_{6}\right){ }^{1} \mathrm{H}$ : H1 (s, 12.88), H2 (s, 7.95), H6 (s, 2.18), H7 (s, 3.81), H9 (t, 2.53), H10 (t, 3.24), $\mathrm{H} 11$ (s, 7.16), H16 (s, 7.30) H17 (s, 2.66); ${ }^{13} \mathrm{C}$ NMR ( $\delta$ ppm, DMSO- $d_{6}$ ) C2 135.2, C4 127.1, C5 117.8, C6 9.8, C7 24.5, C9 30.6, C10 40.6, C12 159.9, C17 28.1. Elemental analysis calculated for $\mathrm{C}_{20} \mathrm{H}_{40} \mathrm{O}_{8} \mathrm{~N}_{12} \mathrm{~S}_{3} \mathrm{Zn}, \mathrm{C} 28.90, \mathrm{H} 4.61, \mathrm{~N} 20.22, \mathrm{~S}$ 7.71; Found C 29.75, H 4.57, N 20.78, S 7.83\%. EM $\left(\mathrm{FAB}^{+}\right)$, $\left(\mathrm{m} / \mathrm{z}\right.$, fragment) $351[\mathrm{Zn}(\mathrm{cime}) \mathrm{Cl}]^{+}, 158[\mathrm{Zn}(\mathrm{cime})]^{2+}$.

\section{Computational details}

The geometry of all structures was fully optimized using the density functional theory (B3LYP) $[35,37]$ in combination with the def2-TZVP basis set using the Gaussian 09 software 
package [38], and their vibrational frequencies were computed at the same level of theory. All calculations are true minimal, since the values of the vibrational frequencies are all positive. Results were visualized by using the Chemcraft v1.6 program [38].

\section{Acknowledgements}

We acknowledge financial support from Project IN206707 PAPIIT-DGAPAUNAM and CONACyT-SEP E-43662-F. We thank M. Gutiérrez-Franco, N. López-Balbiaux, V. LemusNeri, R. I. del Villar, G. Duarte and R. P. Fierro-Ramírez for technical support.

\section{References}

1. Kimura, E.; Koike, T.; Shimizu, Y.; Kodamalb M. Inorg. Chem. 1986, 25, 2242-2246.

2. Kanumfre, F.; de Lima, E. M.; Scheidt, G.; Carneiro, P. I. B.; Rosso, N. D. J. Braz. Chem. Soc. 2010, 21, 800-805.

3. Bonora, S.; Foggia, M. D.; Tugnoli, V.; Righi, V.; Benassic, E.; Maris, A. J. Raman Spectrosc. 2011, 42, 612-620.

4. Greenaway, F. T.; Brown, L. M.; Dabrowiak, J. C.; Thompson, M. R. Day, V. W. J. Am. Chem. Soc. 1980, 102, 7782-7784.

5. Soto, L.; Borrás, J.; Sancho, A.; Fuertes, A.; Miravitlles, C. Acta Cryst. 1985, C41, 1431-1433.

6. Soto, L.; Legros, J. P.Polyhedron 1988, 7, 307-314.

7. Abadia, A.; Sancho, A.; Soto, L.; Borrás, J. Transition Met. Chem. 1986, 11, 8-11.

8. Bianucci, A. M.; Demartin, F.; Manassero, M.; Masciocchi N.; Ganadu, M. L.; Naldini, L.; Panzanelli, A. Inorg. Chim. Acta 1991, 182, 197-204.

9. Barańska, M.; Proniewicz, L. M. J. Mol. Struct. 1999, 511-512, 153-162.

10. Nurchi, V.; Cristiani, F.; Crisponi, G.; Ganadu, M. L.; Lubinu, G.; Panzanelli, A.; Naldini, L. Polyhedron 1992, 11, 2723-2727.

11. Crisponi, G.; Cristiani, F.; Nurchi, V. M.; Silvagni, R.; Ganadu, M. L.; Lubinu, G.; Naldini, L.; Panzanelli, A. Polyhedron 1995, 14, 1517-1530.

12. Onoa, G. B.; Moreno, V.; Freisinger, E.; Lippert, B. J. Inorg. Biochem. 2002, 89, 237-247.

13. Tella, A. C; Eke, U. B.; Isaac, A. Y.; Ojekanmi, C. A. Orbital Elec. J. Chem,. Campo Grande, 2011, 3, 94-103.

14. Tirmizi, S. A.; Wattoo, F. H.; Wattoo, M. H. S.; Sarwar, S.; Memon, A. N.; Iqbal, J.; Ghanghro, A. B. Arabian J. Chem. 2012, $5,309-314$.

15. Ito, M.; Inaguma, K.; Suzuki, Y.; Segami, T.; Suzuki. Y. Japan. J. Pharmacol, 1995, 68, 287-295.

16. Shibata, M.; Kokubo, H.; Morimoto, K.; Morisaka, K.; Ishida, T.; Inoue, M. J. Pharm. Sci. 1983, 72, 1436-1442.
17. Mitchell, R. C. J. Chem. Soc. Perkin Trans. 2 1980, 915-918.

18. Hädicke, E.; Frickel, F.; Franke, A. Chem. Ber. 1978, 111, 32223232.

19. Byrn, S. R.; Graber, C. W.; Midland, S. L. J. Org. Chem. 1976, 41, 2283-2288.

20. Saran, A.; Srivastava, S.; Kulkarni, V. M.; Coutinho, E. Indian J. Biochem. Biophys. 1992, 29, 54-64.

21. Tudor, A. M.; Davies, M. C.; Melia, C. D.; Lee, D. C.; Mitchell, R. C.; Hendra, P. J.; Church, S. J. Spectrochim. Acta Part A: Mol. Spectroscopy 1991, 47, 1389-1393.

22. Kojic-Prodic, P.; Kajfer, F.; Belin, B.; Toso, R.; Sunjic, V. Gazz. Chim. Ital., 1979, 109, 535-539.

23. Middleton, D. A.; Le Duff, C. S.; Berst, F.; Reid, D. G. J. Pharm. Sci. 1997, 86, 1400-1402.

24. Párkányi, L.; Kálmán, A.; Hegedüs, B.; Harsányi, K.; Kreidl, J. Acta Crystallogr. 1984, C40, 676-679.

25. Danesh, A.; Chen, X.; Davies, M. C.; Roberts, C. J.; Sanders, G. H. W.; Tendler, S. J. B.; Williams, P. M.; Wilkins, M. J. Langmuir 2000, 16, 866 .

26. United States Pharmacopeial Convention. USP XXIII. United States Pharmacopeia. 23 ed. Easton: Mack Printing; 1995.

27. Kumar, R.; Singh, R. Turk. J. Chem.; 2006, 30, 77- 87.

28. Weder, J. E.; Dillon, C. T.; Hambley, T. W.; Kennedy, B. J.; Lay, P. A.; Biffin, J. R.; Regtop, H. L.; Davies, N. M.; Coord. Chem. Rev. 2002, 232, 95-126.

29. Oberley, L.W.; Buettner, G.R.; Cancer Res. 1979, 39, 11411149.

30. El-Ayaan, U.; Gabr. I. M. Spectrochim. Acta Part A 2007, 67, 263-272.

31. García, M. S.; Albero, M. I.; Sánchez-Pedreño, C.; Abuherba, M.S.; J. Pharm. Biomed. Anal. 2003, 32, 1003-1010.

32. Hinojosa, M.; Ortiz, R.; Perelló, L.; Borrás, J.; J. Inorg. Biochem., 1987, 29, 119-129.

33. Sancho, A.; Borras, J.; Soto-Tuero, L.; Esteban-Calderón, C.; Martínez-Ripoll M.; García-Blanco, S.; Polyhedron, 1985, 4, 539-543.

34. Batsanov, S. S. Inorg. Mater. 2001, 37, 871-885.

35. Becke, A. D. J. Chem. Phys. 1993, 98, 5648-5652.

36. Lee, C.; Yang, W.; Parr, R. G. Phys. Rev. 1988, B37, 785-789.

37. Gaussian 09, Revision B.01, Frisch, M. J.; Trucks, G. W.; Schlegel, H. B.; Scuseria, G. E.; Robb, M. A.; Cheeseman, J. R.; Scalmani, G.; Barone, V.; Mennucci, B.; Petersson, G. A.; Nakatsuji, H.; Caricato, M.; Li, X.; Hratchian, H. P.; Izmaylov, A. F.; Bloino, J.; Zheng, G.; Sonnenberg, J. L.; Hada, M.; Ehara, M.; Toyota, K.; Fukuda, R.; Hasegawa, J.; Ishida, M.; Nakajima, T.; Honda, Y.; Kitao, O.; Nakai, H.; Vreven, T.; Montgomery, Jr., J. A.; Peralta, J. E.; Ogliaro, F.; Bearpark, M.; Heyd, J. J.; Brothers, E.; Kudin, K. N.; Staroverov, V. N.; Kobayashi, R.; Normand, J.; Raghavachari, K.; Rendell, A.; Burant, J. C.; Iyengar, S. S.; Tomasi, J.; Cossi, M.; Rega, N.; Millam, J. M.; Klene, M.; Knox, J. E.; Cross, J. B.; Bakken, V.; Adamo, C.; Jaramillo, J.; Gomperts, R.; Stratmann, R. E.; Yazyev, O.; Austin, A. J.; Cammi, R.; Pomelli, C.; Ochterski, J. W.; Martin, R. L.; Morokuma, K.; Zakrzewski, V. G.; Voth, G. A.; Salvador, P.; Dannenberg, J. J.; Dapprich, S.; Daniels, A. D.; Farkas, Ö.; Foresman, J. B.; Ortiz, J. V.; Cioslowski, J.; Fox, D. J. Gaussian, Inc., Wallingford CT, 2009.

38. ChemCraft v1.6, G.A. Zhurko, G. A.; Zhurko, D. A. 